\title{
Kenaikan Harga Ayam Pada Masa Covid-I9 di Kota Palangkaraya (Analisis Pemikiran Ibnu Taimiyah tentang Regulasi Harga)
}

\author{
Eka Sri Apriliana* \\ Ariyadi, S.HI., M.H ${ }^{2 *}$ \\ ${ }^{*}$ Pascasarjana IAIN Palangkaraya Kalimantan Tengah, Indonesia \\ ${ }^{*}$ Universitas Muhammadiyah Palangkaraya
}

\begin{abstract}
Abstrak
Penelitian ini bertujuan untuk menganalisis kenaikan harga ayam selama masa COVID- 19 dengan pemikiran Ibnu Taimiyah tentang regulasi harga.Penelitian ini menggunakan pendekatan kualitatif dengan metode kepustakaan melalu beberapa buku dan jurnal yang berkaitan dengan pemikiran Ibnu Taimiyah tentang regulasi harga.Analisisnya menggunakan deskriptif dengan tujuan menggambarkan kenaikan harga ayam dengan pemikiran lbnu Taimiyah. Hasil analisis dari penelitian ini adalah kenaikan harga ayam di kota palangkaraya menurut pemikiran lbnu Taimiyah tentang regulasi harga menyarankan harus melibatkan peran pemerintah dalam menentukan harga ayam di pasar kerena dilihat dari kenaikan secara signifikan mengakibatkan ketidakadilan harga di pasar.
\end{abstract}

Kata Kunci: Kenaikan harga ayam, Regulasi Harga, Ibnu Taimiyah, COVID-19

\begin{abstract}
This study aims to analyze the increase in chicken prices during the COVID-19 period with Ibn Taymiyah's thoughts about price regulation. This study uses a qualitative approach with a library method through several books and journals related to Ibn Taymiyah's thoughts on price regulation. His analysis uses descriptive with the aim of describing the increase in chicken prices with the thought of Ibn Taymiyah. The results of the analysis of this study are the increase in chicken prices in the city of Palangkaraya according to Ibnu Taimiyah's thinking about price regulation suggesting that it should involve the government's role in determining the price of chicken on the market because it is seen from a significant increase resulting in price injustice in the market.
\end{abstract}

Keywords: Increase in chicken prices, Price Regulation, Ibnu Taimiyah, COVID-19

\section{PENDAHULUAN}

Gejolak harga yang terus menerus naik tanpa terbendungi mengakibatkan kebutuhan barang-barang pokok naik, hal ini sangat dirasakan masyarakat kota Palangkaraya. Bagaimana tidak

masyarakat yang sangat memerlukan barang-barang pokok tersebut terpaksa menahan beberapa keinganannya untuk membeli.Kenaikan harga barang-barang pokok ini disebabkan oleh beberapa faktor salah satu penyebab yang sangat mendukung yaitu adanya sebuah virus yang yang bernama COVID- 19.Virus tersebut mematikan semua aspek ekonomi yang sedang berjalan.Ada banyak kerugian yang di dapat masyarakat dan pemerintah di seluruh dunia tidak hanya di Indonesia saja.

Dalam jurnal Silpa Hanoatubun (2020: 53146) menjelaskan bahwa Coronaviruses (Cov) adalah virus yang menginfeksi sistem pernapasan.Infeksi virus ini disebut COVID19.Virus Corona menyebabkan penyakit flu biasa sampai penyakit yang lebih parah seperti Sindrom Pernafasan Timur Tengah (MERS-CoV) dan Sindrom Pernafasan Akut Parah (SARS-CoV).

Fenomena COVID-19 membuat kenaikan harga tidak hanya terjadi pada bahan pangan beras akan tetapi juga pada komoditas bahan kebutuhan pokok lainnya terutama daging ayam potong. Menururt Venti Eka Satya (2016: 13-16) dalam jurnalnya mengatakan bahwa kenaikan ayam sebagai bahan kebutuhan pokok masyarakat Palangkaraya sangat mempengaruhi daya beli masyarakat. Kutipan tribunnews (2 mei 2020) menyatakanharga ayam di kota palangkaraya mengalami kenaikkan yang signifikan mencapai Rp70 ribu - Rp80 ribu perkilogram.

Kenaikan harga yang tidak wajar ditambah keadaan yang saat ini dialami membuat masyarakat semakin tercekik untuk memenuhi kebutuhan hidup.Harga-harga yang tinggi ini berhubungan dengan pasar,Mul Irwan (2015: 67-68) dalam jurnalnya mengatakan pasar memiliki peranan yang penting dalam ekonomi, karena kemaslahatan manusia dalam mata pencarian tidak mungkin terwujud tanpa adanya saling tukar-menukar.M. Arif Hakim dalam jurnalnya mengatakan pasar adalah sebuah mekanisme pertukaran produk baik berupa barang maupun jasa yang alamiah dan telah berlangsung sejak peradaban awal manusia.Islam menempatkan pasar pada kedudukan yang penting dalam perekonomian.Allah SWT sendiri menerangkan bahwa tidak ada orang yang tidak membutuhkan pasar, karena di pasarlah manusia bisa mendapatkan kebutuhannya. Firman Allah dalam Q.S. Al-Furqaan ayat 20: 


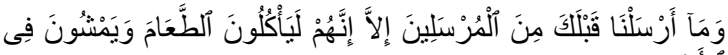

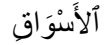

“Dan Kami tidak mengutus rasul - rasul sebelumnya, melainkan mereka sungguh memakan makanan dan berjalan di pasar"

\begin{tabular}{llr}
\multicolumn{2}{c}{ Dengan demikian } & peranan pasar sangat \\
penting dalam & menjalankan roda
\end{tabular}
perekonomian.Tentunya didalam pasar terdapat unsur yang paling penting yaitu harga barang itu sendiri.Syarial Dedi (2020) dalam jurnalnya mengutippemikiran Ibn Taimiyah, bahwa terjadinya fluktuasi harga pasar dipengaruhi oleh permintaan dan ketersediaan barang; harga akan naik jika penawaran meningkat sementara persediaan menipis, begitupun sebaliknya. Hal ini sudah merupakan hukum alam, yang disebut dengan mekanisme pasar.Pemerintah tidak dibenarkan untuk ikut campur. Teori inilah yang diistilahkan oleh ekonomi Barat dengan 'supply dan demand'. Namun, di sisi lain pemerintah selaku penguasadiberi tugas dan wewenang mengurus rakyatnya. Dalam hal ini keikutsertaan pemerintah tidak dapat dielakkan.Rakyat bahkan diwajibkan untuk mentaati perintah penguasa.Dari fenomena tersebut jika kita berkaca kepada pemikiran Ibnu Taimiyah maka ada beberapa point yang dapat di analisisdengan pemikiran beliau tentang regulasi harga.Oleh sebab itu penulis merasa perlu adanya kajian yang lebih mendalam terhadap jurnal ini.

\section{METODE PENELITIAN}

Penelitian ini merupakan penelitian kepustakaan (library reseach) dengan pendekatan kualitatif.Menurut Mestika Zed (2014) penelitian kepustakaan adalah penelitian yang dilakukan oleh peneliti dengan mengumpulkan sejumlah bukubuku, majalah, liflet, jurnal, dan lain-lainnya yang berkaitan dengan penelitian ini.Sementara analisis deskriptif merupakan metode penelitian yang bertujuan untuk menggambarkan atau mendeskripsikan permasalahan secara objektif.

\section{PEMBAHASAN DAN HASIL PENELITIAN}

\section{A. Biografi lbnu Taimiyah}

Dikutip dalam buku Adiwarman Karim (2006: 35I) Taqiyuddin Ahmad bin Abdul Halim atau yang dikenal dengan nama Ibn Taimiyah lahir di kota Harran pada tanggal 22 Januari 1263 M/I0 Rabiul Awal 66I H. Ibn Taimiyah berasal dari keluarga yang berpendidikan tinggi dan termasuk ulama besar Mazhab Hambali. Atas kejeniusannya, sejak usia muda ia telah menamatkan beberapa mata pelajaran, seperti fiqih, tafsir, hadis, filsafat dan matematika dan menjadi unggul di antara temantemannya. la memiliki guru yang berjumlah 200 orang, di antaranya Syamsuddin Al Maqdisi, Ibnu Abi Al Yusr, Ahmad bin Abu Al Khair dan Al
Kamal bin Adul Majd bin Asakir.Menurut Islahi(1997: 7I) pemikirannya yang dianggap revolusioner dan pembaharu, serta ijtihadnya dibidang muamalah membuat namanya semakin terkenal di seluruh dunia.

Dalam kehidupan politik, ia pernah di penjara sebanyak empat kali. Hal ini disebabkan oleh fatwanya yang dianggap bertentangan dengan pemerintah saat itu.ketika di penjara, ia banyak menghabiskan waktu untuk menulis dan mengajar. la menghembuskan nafas terakhirnya pada tanggal 26 September I328 M (20 Zulqa'idah 728 H). (Adiwarman: 2006)

Kutipan buku Amali (2005: 206-207) menyatakan bahwa pembaharu Islam ini juga memiliki banyak karya ilmiah yang sangat fantastis.la memiliki karya buku yang menguraikan tentang hukum, ekonomi, filsafat dan lain-lain. Ibnu Taimiyah juga membahas tentang prinsip-prinsip ekonomi yang ditulis dalam dua kitabnya, yakni alHisbah fi al Islam (lembaga hisbah dalam Islam) dan al-Siyasah al Syar'iyyah fi Ishlah al Ra'i wa al Ra'iyah (hukum publik dan privat dalam Islam). Kitab pertama banyak membahas tentang pasar dan intervensi pemerintah dalam bidang ekonomi, sedangkan kitab kedua membahas tentang pendapatan dan pembiayaan publik.

\section{B. Konsep regulasi harga menurut Ibnu Taimiyah}

Pemikiran Ibnu Taimiyah tentang regulasi harga, yaitu aturan pemerintah terhadap hargaharga barang yang ada di pasar. Tujuannya adalah untuk menegakkan keadilan serta memenuhi kebutuhan pokok masyarakat (Adiwarman: 237). Dalam jurnal Junia Farma (2018: 182-93) memuat hadis yang berhubungan dengan regulagi harga, berkaitan dengan hal ini Nabi Saw menjelaskan dalam hadisnya sebagai berikut:

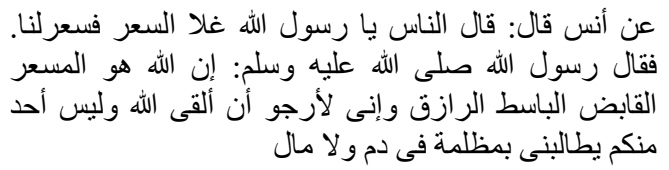
"Dari Anas bin Malik beliau berkata: harga barang-barang pernah mahal pada masa Rasulullah Saw. lalu orang-orang berkata: Ya Rasulullah, harga-harga menjadi mahal, tetapkanlah standar harga untuk kami, lalu Rasulullah bersabda: Sesungguhnya Allahlah yang menetapkan harga, yang menahan dan membagikan rizki, dan sesungguhnya saja mengharapkan agar saya dapat berjumpa dengan Allah Swt dalam keadaan tidak seorang pun di antara kamu sekalian yang menuntut 
saya karena kezaliman dalam pertumpahan darah"

Menurut Ibnu Taimiyah, Hadis tersebut berisi penolakan terhadap regulasi harga, karena termasuk dalam kasus khusus, bukan merupakan kasus yang umum. Oleh karena itu, kenaikan harga bukan disebabkan oleh ketidaksempurnaan pasar, melainkan karena kekuatan permintaan dan penawaran.(Adiwarman: 2006)

Ibnu Taimiyah membuktikan bahwa Nabi Saw.pernah menetapkan harga yang adil dalam beberapa kondisi, yaitu (Amalia: 2I5)

I. Kasus pembebasan budak, di mana harus ada pertimbangan harga yang adil dari budak tersebut tanpa adanya penambahan atau pengurangan harga

2. Kasus perselisihan antara dua orang, yakni pemilik pohon dan pemilik tanah. Dalam hal ini, pemilik tanah merasa terganggu atas pohon orang lain (pemilik pohon) yang tumbuh di area tanahnya, sehingga hal itu dilaporkan kepada Rasul. Kemudian hasil keputusannya adalah Rasul memberikan dua pilihan kepada pemilik pohon, yakni menyerahkan secara sukarela pohon tersebut kepada pemilik tanah atau menjualnya kepada pemilik tanah dengan imbalan ganti rugi yang setara

Dalam buku Qardhawi (1997: 467) menyatakan bahwa penetapan harga menurut lbnu Taimiyah juga dapat dibedakan menjadi dua jenis, yaitu penetapan harga yang tidak adil atau mengandung unsur kezaliman dan penetapan harga yang adil menurut hukum.Sebagaimana pernyataannya:"Memaksa masyarakat untuk menjual barang-barang dagangan tanpaada dasar yang mewajibkannya atau melarang mereka menjual barang-barang yang diperbolehkan merupakan sebuah kezaliman yangdiharamkan"(Adiwarman: 368 )

Dari pernyataan ini dapat dipahami bahwa setiap orang bebas keluar masuk pasar.Namun, unsur-unsur monopolistik dan segala bentuk kecurangan, kolusi dan pemalsuan produk harus dihilangkan dari pasar.Selain itu, jika terjadi keadaan darurat, seperti bencana kelaparan, maka pemerintah harus menetapkan harga dan boleh memaksa pedagang untuk menjual barang-barang kebutuhan pokok, seperti bahan makanan yang dibutuhkan oleh masyarakat.(Adiwarman: 369)

Ibnu Taimiyah juga menjelaskan bahwa sebelum dilakukannya penetapan harga, pemerintah harus mengadakan musyawarah dengan masyarakat atau para tokoh perwakilan pasar terlebih dahulu. $\mathrm{Hal}$ ini bersifat persuasif karena pemerintah memberikan penawaran kepada peserta musyawarah dalam hal penetapan harga, sehingga hasil keputusannya bisa disetujui oleh semua pihak. (Amalia: 216)

\section{Analisis pemikiran Ibnu Taimiyah pada kenaikan harga ayam}

Jika dilihat dari konsep regulasi harga yang ditawarkan oleh Ibnu Taimiyah merupakan contoh pemikiran yang sangat bagus.Dalam pandangan Ibnu Taimiyah pemenuhan kebutuhan pokok manusia menjadi tanggung jawab negara atau pemerintah, baik itu pangan, sandang, papan dan sebagainya.Oleh karena itu, penetapan harga yang dilakukan oleh pemerintah dipandang baik, namun hal itu tidaklah bersifat absolut.Maksudnya hanya dalam kondisi tertentu saja pemerintah boleh ikut campur dalam menetapkan harga seperti saat harga mengalami kenaikan karena terjadinya ketidakadilan atau ketidaksetaraan mekanisme pasar yang disebabkan oleh penjual yang menimbung barang pokok yang kemudian dijual kembali.Dalam kondisi serupa seperti itu, kini dianjuran adanya pengawasan atas peningkatan harga. (Islahi: 2I5)

Salah satu berita Kalteng post (2020) menjelaskan bahwa selama masa Covid-19 ada peningkatan harga kebutuhan pokok yangterjadi di kota Palangkaraya, salah satunya kebutuhan pokok yang meningkat drastis yaitu peningkatan harga ayam yang sangat tinggi.jika dikaitkan dengan pemikiran Ibnu Taimiyah, ketika terjadi ketidakstabilan harga, dimana harga kebutuhan pokok naik kerena adanya manipulasi atau praktek monopoli dari sekelompok orang maka dalam hal ini pemerintah harus menetapkan harga.

Dikutip dari berita republika (2020) mengatakan bahwa harga ayam pada tingkat pedagang pasar besar di kota Palangkaraya terus meroket hingga mencapai Rp 70 ribu per kilogram. Kenaikan harga daging ayam tersebut disebabkan karena pasokan daging ayam potong darikota Banjarmasin menghentikan sementara pengiriman ayam potong sehingga mengakibatkan menipisnya pasokan daging ayam di Palangkaraya.

Kenaikan harga ayam tersebut jika kita lihat dari pemikiran Ibnu Taimiyah tentang regulasi harga maka dapat dianalisis bahwa kenaikan harga yang terjadi saat ini disebabkan oleh penetapan harga yang tidak adil, penetapan ini terjadi akibat persaingan pasar bebas yaitu kelangkaan supply (penawaran) yang dilakukan produsen ayam potong.Dalam kasus ini lbnu Taimiyah menyarankan kepada pemerintah agar melakukan kebijakan penetapan harga pada saat ketidaksempurnaan melanda pasar.Sehingga dalam kasus yang terjadi saat ini ditengah-tengah wabah virus corona, peran pemerintah diperlukan untuk menstabilkan harga ayam potong. 
Peran pemerintah sangat diperlukan agar tidak terjadi ketimpangan harga ayam potong di kota Palangkaraya dan diluar kota Palangkaraya. Menurut Ibnu Taimiyah sebelum menetapkan kebijakan penetapan harga, terlebih dahulu pemerintah harus melakukan musyawarah dengan masyarakat terkait. Berkaitan dengan hal ini, lbnu Taimiyah menjelaskan

"Penguasa harus menyelenggarakan
musyawarah dengan para tokoh yang
merupakan wakil dari pelaku pasar.Anggota
masyarakat lainnya juga diperkenankan
menghindari musyawarah tersebut sehingga
dapat menyembunyikan pernyataan
mereka.Setelah melakukan musyawarah dan
penyelidikan terhadap pelaksanaan transaksi jual
beli, pemerintah harus meyakinkan mereka pada
suatu tingkat harga yang dapat membantu
mereka dan masyarakat luas, hingga mereka
menyetujuinya. Harga tersebut tidak boleh
ditetapkan tanpa persetujuan dan izin dari
mereka"(Adiwarman: 373)

Secara jelas dari pernyataan diatas Ibnu Taimiyahmengatakan bahwa sebelum harga itu ditetapkan maka pemerintah harus melakukan musyawarah dengan para tokoh dari wakilpelaku pasar dan masyarakat (penjual atau pembeli)agar tidak menimbulkan ketidakadilan harga ayam potong itu sendiri dan penjual serta pembeli dapat merasakan keuntungan tanpa ketidakadilan harga ayam potonga tersebut. keikutsertaan pemerintah dalam penetapan harga melalui proses musyawarah dapat menciptakan rasa tanggung jawab antara penjual, pembeli, dan pemerintah sehingga terwujudnya harga ayam potong yang kembali normal seperti dulu.

\section{Penutup}

Berdasarkan pemaparaan diatas maka disimpulkan bahwa kenaikan harga ayam potong yang terjadi di kota Palangkaraya dilihat dari pemikiran Ibnu Taimiyah disebabkan oleh penetapan harga yang tidak adil, penetapan ini terjadi akibat persaingan pasar bebas yaitu kelangkaan supply (penawaran) yang dilakukan produsen ayam potong. Dalam kasus ini lbnu Taimiyah menyarankan kepada pemerintah agar melakukan kebijakan penetapan harga pada saat ketidaksempurnaan melanda pasar.Sehingga dalam kasus yang terjadi saat ini ditengah-tengah wabah virus corona, peran pemerintah diperlukan untuk menstabilkan harga ayam potong.

Disarankan kepada pemerintah untuk turut serta dalam menentukan regulasi harga ayam potong agar tidak ada kenaikan dan kelangkaan pada ayam tersebut yang terjadi saat ini, sehingga teciptanya keadilan harga yang disetujui oleh pembeli dan penjual.

\section{Daftar Pustaka}

Ariyadi, Ariyadi. "Bisnis Dalam Islam." Jurnal Hadratul Madaniyah 5.I (2018): I3-26.

\begin{tabular}{|c|c|c|}
\hline Ariyadi, & $\begin{array}{c}\text { Ariyadi. } \\
\text { KOSMOPOLITANISME }\end{array}$ & $\begin{array}{r}\text { "BUDAYA } \\
\text { DALAM }\end{array}$ \\
\hline & PRAKTIK JUAL BELI & PASAR \\
\hline & TERAPUNG PADA & KALIMANTAN \\
\hline & $\begin{array}{l}\text { SELATAN." At-Taradhi: } \\
\text { Ekonomi } 9.2 \text { (2019): 84-90. }\end{array}$ & Jurnal Studi \\
\hline
\end{tabular}

Amalia.Sejarah Pemikiran Ekonomi Islam: Dari Masa Klasik Hingga Kontemporer. Jakarta: Gramata Publishing, 2005.

Dedi, Syarial. “Ekonomi Dan Penguasa (Pemikiran Ibn Taimiyah Tentang Mekanisme Pasar) | Dedi | AL-FALAH : Journal of Islamic Economics." Accessed June I, 2020. http://journal.iaincurup.ac.id/index.php/alfa lah/article/view/442.

Farma, Junia. “Mekanisme Pasar Dan Regulasi Harga: Telaah Atas Pemikiran Ibnu Taimiyah." Cakrawala: Jurnal Studi Islam I3, no. 2 (2018): I82-93. https://doi.org//0.3 1603/cakrawala.v|3i2.2 387.

Hakim, M. Arif. "Peran Pemerintah Dalam Mengawasi Mekanisme Pasar Dalam Perspektif Islam." IQTISHADIA 8, no. I (April 6, 2016). https://doi.org// 0.2 1043/iqtishadia.v8il.10 79.

Hanoatubun, Silpa. "Dampak Covid - 19 Terhadap Prekonomian Indonesia." EduPsyCouns: Journal of Education, Psychology and Counseling 2, no. I (April 14, 2020): 14653.

Republika Online. "Harga Ayam Potong di Palangka Raya Melejit Hingga Rp 70 Ribu,” May 28, 2020.

https://republika.co.id/share/qazto3423.

Banjarmasin Post. "Harga Ayam Potong Sempat Naik, Kapolresta Palangkaraya Langsung Pantau Pasar Tradisional." Accessed June 2, 2020.

https://banjarmasin.tribunnews.com/2020/ 05/29/harga-ayam-potong-sempat-naikkapolresta-palangkaraya-langsung-pantaupasar-tradisional.

Irawan, Mul. "Mekanisme Pasar Islami Dalam Konteks Idealita Dan Realita (Studi Analisis Pemikiran Al-Ghazali Dan Ibnu Taimiyah)." JEBIS (Jurnal Ekonomi Dan Bisnis Islam) I, no. I (20I5): 67-78. https://doi.org/ 10.20473/jebis.vlil.l 434.

Islahi. Konsepsi Ekonomi Ibnu Taimiyah. Surabaya: Bina Ilmu Offset, 1997. 
kaltengpos.co. "Harga Ayam Potong di Pasar Sempat Melejit Rp. 80 ribu, Warga Berallih ke Bahan Pokok Ini."

kaltengpos.co. Accessed June 4, 2020.

https://kaltengpos.co/berita/-4695I -

harga_ayam_potong_di_pasar_sempat_ melejit_rp._80_ribu,_warga_berallih_ke_ bahan_pokok_ini_html.

Karim, Adiwarman Azwar. Sejarah Pemikiran Ekonomi Islam. Jakarta: PT RajaGrafindo Persada, 2006.

Qardhawi. Peran Nilai Dalam Perekonomian Islam. (Terj. Didin Hafiduddin). Jakarta: Robbani Press, 1997.

Satya, V. Eka. "Anomali Fluktuasi Harga Bahan Pangan Di Indonesia." Info Singk. Ekon. Dan Kebijak. Publik 8, no. 3 (20I6): I3-I6.

Zed, Mestika. Metode peneletian kepustakaan. Yayasan Obor Indonesia, 2004. 